\title{
METHODOLOGY OF ESTIMATION OF METHANE EMISSIONS FROM COAL MINES IN POLAND
}

\author{
RENATA PATYŃSKA \\ Department of Rockburst and Rock Mechanics, Central Mining Institute, pl. Gwarków 1, 40-166 Katowice, Poland, \\ e-mail: r.patynska@gig.eu
}

\begin{abstract}
Based on a literature review concerning methane emissions in Poland, it was stated in 2009 that the National Greenhouse Inventory 2007 [13] was published. It was prepared firstly to meet Poland's obligations resulting from point 3.1 Decision no. 280/2004/WE of the European Parliament and of the Council of 11 February 2004, concerning a mechanism for monitoring community greenhouse gas emissions and for implementing the Kyoto Protocol and secondly, for the United Nations Framework Convention on Climate Change (UNFCCC) and Kyoto Protocol.

The National Greenhouse Inventory states that there are no detailed data concerning methane emissions in collieries in the Polish mining industry. That is why the methane emission in the methane coal mines of Górnośląskie Zagłębie Węglowe - GZW (Upper Silesian Coal Basin - USCB) in Poland was meticulously studied and evaluated. The applied methodology for estimating methane emission from the GZW coal mining system was used for the four basic sources of its emission. Methane emission during the mining and post-mining process. Such an approach resulted from the IPCC guidelines of 2006 [10].

Updating the proposed methods (IPCC2006) of estimating the methane emissions of hard coal mines (active and abandoned ones) in Poland, assumes that the methane emission factor (EF) is calculated based on methane coal mine output and actual values of absolute methane content. The result of verifying the method of estimating methane emission during the mining process for Polish coal mines is the equation of methane emission factor EF.
\end{abstract}

Key words: methane emission, statistical analysis, coal mine

\section{INTRODUCTION}

Based on statistical analysis conducted at the Central Mining Institute (CMI) in the form of the "Annual Report (for the years 2001-2010) on the State of Basic Natural and Technical Hazards in the Hard Coal Mining Industry" [1], in the chapter concerning the gas hazard, data concerning hard coal output, absolute methane emissions, methane drainage and methane management from mines in the Upper Silesian Coal Basin in the years 2001-2010 were specified. For each of the analysed years, it was possible to separate output quantities from mines classified as CMM (Coal Mine Methane) mines. On this basis, the number and output of mines defined as CMM mines have been estimated. The Annual Report states that methane and the related explosion hazard is one of the most dangerous phenomena accompanying hard coal production in the Polish mining industry.

Between 2001-2010, exploitation of coal seams in Poland was conducted in mines specified in the Annual Report (for the years 2001-2010) on the state of basic natural and technical hazards in the hard coal mining industry [1].

Summarising the statistical analysis of the Annual Report [1] (Fig. 1) it should be stated that between 2001-2010 the production and number of operating hard coal mines in the Polish hard coal mining industry were subject to a considerable decrease. Coal output of 102.78 million tons was reduced to 76.15 million tons. The exploitation of seams was realised in 43 mines in 2001 but because of closure and the merging of mines, this fell to 29 by 2010 . There were $30 \mathrm{CMM}$ mines in 2001 producing coal at the level of 72.37 million tons, which had fallen to 21 mines producing 52.18 million tons of coal by 2010 .

Polish hard coal deposits, especially in the central, southern and southwestern part of the Upper Silesian Coal Basin, belong to deposits that have high methane content [1]. The carboniferous deposits are covered by an overburden of non-permeable neogen and quaternary layers of great thickness, which have caused the methane to remain in the coal seams. High methane saturation creates a hazard during the conducting of 
mining operations. Methane emissions from Polish hard coal mines concern:

- areas of mined longwalls,

- post-mining gobs,

- drilled development excavations.

Despite considerable progress in the recognition and tackling of the methane hazard, its growth in many mining areas of the Upper Silesian Coal Basin in Poland has been observed. This is connected with the increase in depth of the mining operation, exploiting seams with higher methane content and gas deposit pressure.

Exploitation at greater depths in seams highly saturated with methane has caused accumulation of emitted methane in a small number of longwall workings and thus, the growth of their absolute methane emissions.
The statistical analysis or results of mining catastrophes caused by methane or methane and coal dust explosions in the history of the Polish underground mining sector are most tragic, both on account of the number of fatalities and serious accidents, as well as the amount of material damage caused [11].

Investigations into methane explosions that have occurred have contributed to the development of the methods and means for recognition and prediction of the methane hazard, extension of the control of the methane content in the air of excavations and the development of the means and methods for combating it, including methane drainage. The correct recognition of the methane hazard state and its efficient control has basic significance in conducting safe exploitation [14].

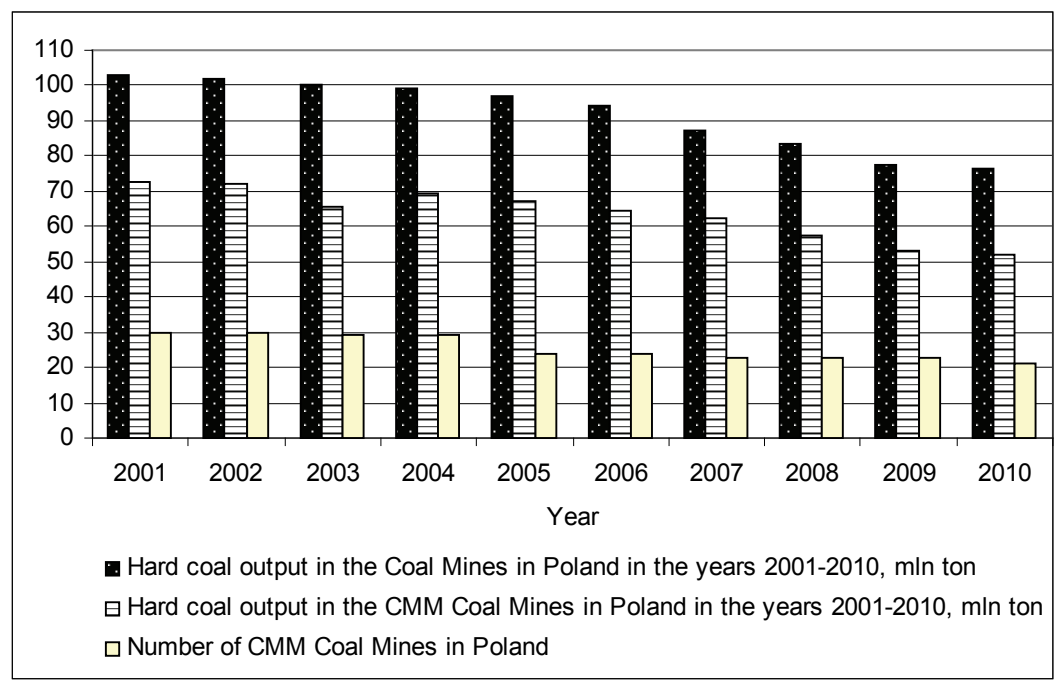

Fig. 1. Production of hard coal in CMM coal mines

against the background of the number of CMM mines in the years 2001-2010

Collecting and organisation of data on methane emission in hard coal mines (active and abandoned) in Poland from last 10 years (2001-2010)

\begin{tabular}{|c|c|c|c|c|c|c|}
\hline Year & $\begin{array}{c}\text { Number } \\
\text { of CMM } \\
\text { Coal Mines } \\
\text { in Poland }\end{array}$ & $\begin{array}{l}\text { Hard coal output } \\
\text { in the CMM } \\
\text { Coal Mines } \\
\text { in Poland, } \\
\text { mln t }\end{array}$ & $\begin{array}{l}\text { Relative methane emissions } \\
\text { from active coal mines } \\
\text { in Poland - mining - ventilation } \\
\text { methane emission (VAM), } \\
\mathrm{m}^{3} / \text { tonne }\end{array}$ & $\begin{array}{c}\text { Relative methane } \\
\text { emissions from } \\
\text { degassing systems, } \\
\mathrm{m}^{3} / \text { tonne }\end{array}$ & $\begin{array}{c}\text { Relative methane } \\
\text { emissions - loss } \\
\text { emissions, } \\
\mathrm{m}^{3} / \text { tonne }\end{array}$ & $\begin{array}{c}\text { Absolute methane } \\
\text { emissions from } \\
\text { abandoned mines } \\
(\mathrm{AMM}) \text { in Poland, } \\
\mathrm{mln} \mathrm{m}^{3} / \text { year }\end{array}$ \\
\hline 2001 & 30 & 72.37 & 300.22 & 82.74 & 30.71 & 0.91 \\
\hline 2002 & 30 & 72.13 & 304.08 & 78.11 & 30.91 & 0.73 \\
\hline 2003 & 29 & 65.71 & 345.69 & 92.08 & 40.57 & - \\
\hline 2004 & 29 & 69.17 & 320.26 & 91.14 & 38.41 & - \\
\hline 2005 & 24 & 67.35 & 287.98 & 87.57 & 37.23 & - \\
\hline 2006 & 24 & 64.52 & 305.62 & NA & NA & - \\
\hline 2007 & 23 & 62.47 & 325.56 & 101.33 & 38.20 & - \\
\hline 2008 & 23 & 57.54 & 361.11 & 116.40 & 51.15 & - \\
\hline 2009 & 23 & 53.27 & 385.35 & 120.09 & 43.18 & - \\
\hline 2010 & 21 & 52.18 & 350.78 & 110.82 & 38.58 & - \\
\hline
\end{tabular}


With consideration of the above-mentioned factors, the Central Mining Institute produces a report about the state of the methane hazard in the Polish mining industry.

Using the data presented in the present Annual Report [1] (Table 1), data related to the output and quantity of emitted methane from individual mines have been specified. The statistical analysis produced in the Annual Report, in the years 2001-2010 in the Polish coal mining industry show that one mine was closed, namely the Niwka-Modrzejów colliery; however, measurements of methane emissions were continued until 2002.

Over time, the efforts regarding methane drainage have brought positive effects.

Every year, the quantity of methane captured by methane drainage systems and the quantity of utilised methane increases.

\section{METHANE EMISSIONS INVENTORY IN MINES IN THE UPPER SILESIAN COAL BASIN IN POLAND - STATE OF THE ART}

In Poland in 2009 the National Inventory Report on Greenhouse Gas Emissions and Absorption for 2007 [13] was published, which was prepared to fulfil the obligations of Poland in conforming to the requirements of article 3.1 of the decision No. 280/2004/EC of the European Parliament and of the Council of 11 February 2004 concerning a mechanism for monitoring Community greenhouse gas emissions and for implementing the Kyoto Protocol, as well as for the needs of the United Nations Framework Convention on Climate Change (UNFCCC) and Kyoto Protocol (Kyoto Protocol for United Nations Framework Convention on Climate Change. III Conf. of Paris, December 1997).

The key proof regarding the fulfilment of obligations in relation to the convention and its protocol is the elaboration of annual greenhouse gas emission and absorption inventory by the parties of the convention. The information contained in the report [13] was prepared in accordance with the updated guidelines (decision 14/CP.11): "Guidelines for the Preparation of National Communications by Parties included in Annex I to the Convention, Part I: UNFCCC Reporting Guidelines on Annual Inventories" (included in the document FCCC/SBSTA/2006/9). The report has also been supplemented by additional information to conform to the requirements of article 7.1 of the Kyoto Protocol and determined recommendations in the decision 15/CMP.1.
The report of the National Emissions Inventory Centre [13] is the equivalent of the English National Inventory Report (NIR) and presents the results of the national inventory of greenhouse gas emissions and absorption in Poland in 2007. The inventory comprised greenhouse gases, including methane $-\mathrm{CH}_{4}$.

The current applied methodology for the estimation of greenhouse gas emissions is consistent with the guidelines in force, prepared by the Intergovernmental Panel on Climate Change (IPCC 1997, IPCC 2000) [8], [9]. Here, national methods of emission estimation consistent with the latest IPCC guidelines (2006) [10] have been used, to reflect the specificity of Polish conditions.

The methodology, emission factors, data about activities and measurements applied in the Polish inventory until 2007 have been described in chapters 3-8 of the Report of the National Emissions Inventory Centre [13]. It is important to mention here that the terms "sector" and "category" (subsector and subcategory) are used interchangeably in the report and refer to the categories of emission sources included in the IPCC guidelines (2000).

The emission sources in all categories are identified as main emission sources based on their share in national emissions and/or assessment of emission trend in conformity with the methodology of IPCC 2000 [9]. Full tables prepared in conformity with the guidelines [8], including the assessment of level of emission and assessment of trends were presented in Annex 1 in [13].

The report of the National Emissions Inventory Centre [13] presents in Tables 2.2 and 2.3 that methane emissions in Poland in 2007 for solid fuels, including hard coal, amount to $410.05 \mathrm{Gg}$, which constitutes a $23.77 \%$ share in individual categories of national $\mathrm{CH}_{4}$ emissions. Methane emissions (without category 5) in 2007 amounted to $1725.01 \mathrm{Gg}$, i.e., 36.23 million tons of $\mathrm{CO}_{2}$ equivalent. The share of methane in the total national greenhouse gas emissions in 2007 amounted to $9.1 \%$.

The emissions of the first mentioned categories comprise, among other things, emissions from underground mines (about $23.8 \%$ of total $\mathrm{CH}_{4}$ emissions).

Using the results of two methodological works by Gawlik et al. [3] and Gawlik and Grzybek [6] national emission factors for the following emission sources in hard coal mines were determined:

- from ventilation systems,

- from methane drainage systems,

- from mined-out coal,

- from post-exploitation (post-extraction) processes. 
Also the results from the work (Kwarciński et al., 2005) [12], were specified in the table PIG, 2008 [17], in which once again the emission factors have been estimated on the basis of very detailed data and measurements for the year 2003. Furthermore, a thorough analysis of emission factors was carried out, comparing them with the results of previous works. For the needs of the national inventory the emission factors per ton of mined coal were calculated; these values are generally available, for example, from the publication of the State Geological Institute (PIG) [17].

Following the analysis, the selection of emission factors was carried out for ventilation systems, methane drainage (degasification) systems, post-exploitation (post-extraction) processes, waste from productive and abandoned mines, for individual years in the period 1988-2007, based on the above-mentioned sources [12], [13].

To conform with procedure for the solid fuel sector, an analysis of uncertainty of data, in accordance with the international guidelines included in the IPCC [9], [10] guidelines and determined as method Tier 1, has been carried out. In the national inventory [13] the results of this analysis were summarised; wider information about the accuracy of data and a full uncertainty analysis can be found in the annex to this report.

The uncertainty assessed for individual categories of sources indicates the value of $41.9 \%$ for subcategory B.1. solid fuels, in which methane emissions from hard coal systems were also taken into account.

The assessment of methane emission levels indicates that coal mining is in seventh place with respect to the share of total methane emissions in 2007, if sector 5 is not taken into account and in eighth place if it is. In turn, the assessment of the trend for methane emission sources (without consideration of sector 5) indicates that coal mining is in fifth place with its share amounting to $3.495 \%$ and in sixth place with a share amounting to $2.937 \%$, if sector 5 is taken into account [13].

\section{UPDATING METHODOLOGY OF ESTIMATION OF METHANE EMISSIONS CONNECTED WITH HARD COAL EXPLOITATION IN POLAND - HARD COAL SYSTEM}

Mentioned in both the Report of the National Emissions Inventory Centre [13] and in the publication of the State Geological Institute [17], the method for estimation of methane emissions of the hard coal mines system in Poland is at present recommended and used in order to estimate greenhouse gas emissions.

According to Kwarciński [12], the methane emission factors used in the national emission inventories for individual sources of the hard coal system, presented in the two methodological works of Gawlik [3], [6] require verification. The results of the work of Kwarciński from 2005, in which emission factors have once again been estimated based on very detailed data and measurements, refer to the year 2003. In this work, a thorough analysis of emission factors was performed, comparing them with the results of previous works. For the requirements of the national inventory, emission factors per ton of mined-out coal were calculated; these values are available in the publication of the above-mentioned State Geological Institute [17].

Both the authors of the above-mentioned works and the IPCC [10] recommendations regarding the estimation of methane emissions from the hard coal system, distinguish:

- methane emissions during the coal exploitation process - underground emissions (ventilation emissions, emissions from degasification systems),

- methane emissions in post-exploitation processes - surface emissions.

Each of the identified emission sources should be treated independently and therefore, the estimation from each source is performed separately using the formula

$$
E=Q_{w} \cdot W
$$

where

$E$ - emission quantity from the given emission source $\left(\mathrm{m}^{3}\right)$, $(\mathrm{t})$,

$Q_{w}$ - activity of the system (coal output quantity)

$W$ - emission factor $\left(\mathrm{m}^{3} / \mathrm{t}\right.$ of mined out coal).

In such a formulation, the emission factor determines the volume of methane liberated into the atmosphere per mass unit (ton) of mined-out coal. Due to the requirements of reporting, the methane volume is converted into a mass $(\mathrm{Gg})$ unit with the application of the coefficient of conversion $0.67\left(\mathrm{t} / \mathrm{million}^{3}\right)$ [8].

The recommendations of the IPCC [10] placed high stress on the improvement of assessment of emission factors. According to the degree of recognition of the methane content of mined coal seams and accessibility of investigation results, the following methods of estimation of methane emissions from hard coal systems are recommended: 
1) method of world averages,

2) specific method for the country (coal basin),

3) specific method for individual mines.

These methods differ considerably with respect to the accuracy of emission estimation.

The specific method for mines can be used in the case of accessibility to detailed measurement results of the methane content of coal seams and data related to methane emissions from mines.

The ventilation emission factors for individual mines can be calculated based on reports of mine ventilation services, included among other things in the yearly Annual Report [1]. The total emissions in the case of the hard coal mines in Poland constitute the sum of the ventilation emissions and methane capture by degasification systems.

The emissions from methane drainage systems in this method are understood as the difference between the quantity of methane captured by methane drainage systems and the methane used. It is also necessary to present the estimation methodology and to identify this part of the methane emissions which would not occur in the case of a lack of methane drainage.

Admittedly, the IPCC recommendations do not foresee the estimation of methane emissions in postexploitation processes by means of the specific method for mines (because the method of country averages is recommended). However, using data from the Annual Report [1], the Statistical Yearbook [18] and Environmental Protection [2], methane emissions from post-extraction processes and surface emissions (from production wastes) in the years 2001-2010 in Poland were determined.

The essential basis of the methodology for estimation of methane emissions from hard coal mines in Poland comprises the study of Kwarciński [12] and the study of the "National Study of Sources and Capture of Greenhouse Gases in Poland", carried out in 1995. In these works, based on data from 1990-1992, the mean methane emission factors for all identified emission sources on the national scale were assessed. These factors constituted the basis of estimations of methane emission from the hard coal system performed for 1988 (base year) and subsequent years and in detail for the year 2003 .

The inventory methodology of methane emissions from the hard coal system has been widely described in the methodological works [3]-[7]. The methodology applied in Poland presented in the above-mentioned elaborations in conformity with IPCC recommendations can be considered as the emission estimation method specific for the country.
According to Kwarciński [12], the course of conduct when estimating methane emissions from the hard coal system in Poland is as follows:

1. Determination of sources of methane emission (emitters) from the system.

2. Analysis of accessibility and collecting of necessary data.

3. Refining the methodology of methane emission estimation from individual emission sources. Calculation of emission factors from determined emission sources.

As necessary, for the development of the methodology of emission estimation from the hard coal system, the following basic data were adopted:

- quantity of coal output from individual mines [1],

- measurement results of residual methane content of mines [12],

- measurement results of absolute methane content, quantity of methane capture by degasification systems as well as utilisation and losses of captured methane [1],

- quantity of production waste stored on the surface [2], [17] and content of coal substance in production wastes (waste rocks) [12].

According to Kwarciński [12], the use of values of the methane content of mined coal seams in CMM mines considerably authenticates the methane emission estimation.

\section{MODIFICATION OF THE METHODOLOGY OF METHANE EMISSION ESTIMATION CONNECTED WITH HARD COAL EXPLOITATION IN POLAND - HARD COAL SYSTEM}

The estimation of methane emissions from individually identified sources was conducted separately, in an independent manner. All calculations were intended to determine the dependence coefficients of emissions from individually identified sources from the data: quantity of coal output and methane content of the mine. The absolute methane emission of a mine was adopted as the sum of ventilation emissions and that methane captured by methane drainage systems, which was acknowledged as capture of methane, which would be released into the atmosphere during exploitation.

Modification of the IPCC [10] methods of estimating methane emission from mining and post- 
mining systems of hard coal mines (active ones and abandoned ones) in Poland, assumes that the methane emission factor (EF) is calculated based on methane coal mine (CMM Coal Methane) output and actual values of absolute methane content.

Estimation of ventilation emissions $E_{w}$ for individual mines was performed based on the formula

$$
E_{w}=W_{e} \cdot Q
$$

where

$Q$ - hard coal output in the CMM Coal Mines (t),

$W_{e}-$ ventilation emission factor $\left(\mathrm{m}^{3} \mathrm{CH}_{4} / \mathrm{t}\right.$ of coal).

Estimation of methane emissions from methane drainage systems - is the adopted value of emissions of losses of captured methane, based on measurements carried out in mines. These emissions are also determined as the difference between the captured and utilised methane.

Estimation of methane emissions in post-exploitation processes was carried out independently:

- in mines, in which the average methane content of mined coal $G_{k}\left(\mathrm{~m}^{3} / \mathrm{t}\right)$ is higher or equal to the residual methane content, the quantity of methane emitted in post-exploitation processes (from 1 ton of coal) equal to the residual methane content was adopted,

- in mines, in which the average methane content of mined coal seam $G_{k}\left(\mathrm{~m}^{3} / \mathrm{t}\right)$ is lower than the residual methane content, the quantity of methane emitted in post-exploitation processes (from 1 ton of coal) equal to the average methane content of the mined seam was adopted.

Estimation of emissions from dumping sites of production waste was carried out similarly to the case of emissions in post-exploitation processes, taking into account the annual quantity of production wastes, adopting according to Kwarciński (2005) [12] the average content of coal substance in production wastes $(15 \%)$ and the methane content of the organic substance.

The range of data applied in the newly proposed methodology of the present study, for estimation of methane emissions from the hard coal system, taking data from the mine concerned. The range and sources of the information considered and measurement results are as follows:

1. The quantity of methane from ventilation systems, given annually by every hard coal mine (in $\mathrm{m}^{3} \mathrm{CH}_{4} /$ year) was adopted based on data presented in the Annual Report [1].

2. The quantity of methane captured in the mine, given annually by every hard coal mine in $\mathrm{m}^{3}$
$\mathrm{CH}_{4} /$ year) was adopted based on data presented in the Annual Report [1].

3 . The quantity of methane emitted into the atmosphere from methane drainage systems, given annually by every hard coal mine (in $\mathrm{m}^{3} \mathrm{CH}_{4}$ /year) was adopted based on data presented in the Annual Report [1].

4. The residual methane content was adopted (according to Kwarciński) [12] with reference to mines, in which exploitable methane resources were calculated, based on data from the literature, or by analogy with neighbouring mines $\left(\mathrm{m}^{3} \mathrm{CH}_{4} / \mathrm{t} \mathrm{pcs}\right)$.

5 . The quantity of generated and mined mineral wastes is given annually by every hard coal mine (ton). The production waste originating during hard coal exploitation, in conformity with the Law of 27 April 2001 on wastes (Journal of Laws of the Republic of Poland No 62, item 628) must be recorded and in an annual cycle reported to the territorially appropriate Marshal of the Local Government Assembly. These data are generally accessible [2], [18].

In accordance with the Order of the Minister of Environment of 27 September 2001, waste originating during exploration, extraction, physical and chemical processing of ores and other minerals, correspond to waste group 01 . The hard coal mining industry contributes the following types of wastes to this group:

- 010102 - wastes from mining of minerals other than metal ores,

- 010412 - wastes originating during washing and purification of minerals other than those mentioned in 010407 and 010411 ,

- 010481 - wastes from coal flotation other than that mentioned in 010480 .

6. Yearly average temperature of ventilation air (return air) measured in the point of volume measurement. Because of the lack of data from direct measurements, a temperature equal to $30{ }^{\circ} \mathrm{C}$ was adopted (according to Kwarciński) [12].

7. The yearly average temperature of mine gas emitted from methane drainage systems is measured at the point of its volume measurement. Because of the lack of data from direct measurement, a temperature equal to $30{ }^{\circ} \mathrm{C}$ was adopted (according to Kwarciński) [12].

8. The quantity of hard coal exploitation ( $Q$, tons) was adopted based on data presented in the Annual Report [1].

9. The methane content (average) of mined coal seams was adopted (according to Kwarciński) [12], based on results of measurements carried out during development operations (driving of roadway excavations in coal $)\left(\mathrm{m}^{3} \mathrm{CH}_{4}\right)$. 
The regulations of the mining law state: "investigations for the determination of methane content of natural origin (methane content of coal seams) in coal in roadway excavations driven in coal seams should be carried out at distances not exceeding $200 \mathrm{~m}$ and additionally at the distance not exceeding $25 \mathrm{~m}$ from ascertained geological disturbances or other disturbances". To conform to these regulations, the measurements are carried out (most often) during the driving of excavations in coal (roadways, drifts), frequently a considerable time before any exploitation is undertaken (most often using the longwall system). However, it should be stressed that the adoption of these methane content measurements takes into account (at least partly) the influence of degasification (methane drainage) of currently mined seams, caused by the exploitation of neighbouring seams. For calculations, the average arithmetical methane content of the mined seam (within the range of conducted exploitation in the analysed year), or in the case of high changeability, of individual deposit parts or even mined longwalls should be assumed.

10. Average values of coal quality (ash content, total moisture content), applied for the conversion of the quantity of mined coal into pure coal substance, were adopted based on results of analyses carried out in the mined seam part. Ash and moisture content is given as a percentage (according to Kwarciński) [12].

\section{ESTIMATION OF METHANE EMISSIONS FROM MINING SOURCES OF THE HARD COAL SYSTEM}

The methane quantity from ventilation systems $\left(E_{w}\right)$ is estimated based on data made accessible through individual hard coal mines and specified in the Annual Report [1]. Ventilation emissions from those mines that do indicate ventilation emissions were not estimated.

The methane quantity from methane drainage (degasification) systems is calculated based on data given through individual hard coal mines and specified in the Annual Report [1].

Emissions from the methane drainage systems $\left(E_{o}\right)$ of each of the mines, where methane drainage is conducted (otherwise called loss emissions), are calculated as the difference of the quantity of captured methane $\left(M_{u i}\right)$ and the quantity of utilised methane $\left(M_{w i}\right)$ or burnt

$$
E_{o}=M_{u i}-M_{w i}\left[\text { million } \mathrm{m}^{3} \mathrm{CH}_{4}\right]
$$

The final value of methane emissions from ventilation and degasification systems is obtained after the conversion of reported individual mines values of methane emissions in standard conditions $\left(293{ }^{\circ} \mathrm{K}\right)$. This conversion is carried out using the formula

$$
E_{o(N)}=E_{o} \cdot 293 /\left(273+t_{p}\right)
$$

where

$E_{o(N)}$ - emissions from methane drainage systems converted into standard conditions $\left(20^{\circ} \mathrm{C}\right)$ [million $\left.\mathrm{m}^{3}\right]$,

$E_{o}$ - emissions from methane drainage systems [million $\mathrm{m}^{3}$ ],

$t_{p}$ - annual average temperature of mine gas $\left[{ }^{\circ} \mathrm{C}\right]$.

Methane emissions from mined-out coal in postexploitation processes are estimated separately for each mine in each of the analysed years. Methane emitted in post-exploitation processes was estimated with the application of hitherto used methodology, which assumes emissions on the surface exclusively of residual methane, at the same time the value of residual methane content was adopted based on data from the work of Kwarciński [12].

As in the methodology used hitherto, according to the mutual relationship of the average methane content of the given coal seam $\left(G_{p k}, \mathrm{~m}^{3} / \mathrm{t} \mathrm{pcs}\right)$ and value of residual methane content $\left(G_{r}, \mathrm{~m}^{3} / \mathrm{t} \mathrm{pcs}\right)$ :

- in seams (parts of seams), in which the average methane content of the given coal seam $\left(G_{p k}, \mathrm{~m}^{3} / \mathrm{t} \mathrm{pcs}\right)$ is higher or equal to the residual methane content $\left(G_{r}, \mathrm{~m}^{3} / \mathrm{t} \mathrm{pcs}\right)$, the quantity of emitted methane in surface processes $\left(e_{p k o}, \mathrm{~m}^{3}\right)$ is calculated according to the following formula

$$
e_{p k o}=M_{w} \cdot(100-W-A) / 100 \cdot G_{r}
$$

where

$M_{w}$ - mass of mined out coal (million $\mathrm{t}$ ),

$W$ - average content of total moisture (\%),

$A$ - average ash content (\%).

- in seams (parts of seams), in which the average methane content of the given coal seam $\left(G_{p k}, \mathrm{~m}^{3} / \mathrm{t} \mathrm{pcs}\right)$ is lower than the residual methane content $\left(G_{r}, \mathrm{~m}^{3} / \mathrm{t} \mathrm{pcs}\right)$, the quantity of emitted methane in surface processes $\left(e_{p k 1}, \mathrm{~m}^{3}\right)$ is calculated according to the formula

$$
e_{p k l}=M_{w} \cdot(100-W-A) / 100 \cdot G_{p k}
$$

where

$M_{w}$ - mass of mined out coal (million $\mathrm{t}$ ),

$W$ - average content of total moisture (\%),

$A$ - average ash content (\%).

Methane emitted in post-exploitation processes was estimated based on experimentally obtained relationships of methane emissions from coal samples in 
relation to the average methane content of the mined coal. This relationship assumes, in accordance with investigation results, that coal on the surface may still contain dynamically desorbable methane, as well as deeper degasification of coal below the residual methane content taking place in underground excavations and incomplete emissions of residual methane on the surface. The quantity of methane emissions from the analysed seam $\left(e_{p k n}\right)$ can be determined as

$$
e_{p k n}=M_{w} \cdot(100-W-A) / 100 \cdot\left(0.2144177 \cdot G_{p k}\right) .
$$

The final estimated value of methane emissions from the mined coal seam (part of seam) is defined through the arithmetic mean of these two results.

$$
e_{p k}=\left(e_{p k o}+e_{p k n}\right) / 2 \text {. }
$$

Methane emission from the entire mine $\left(E_{p k}\right)$ is the sum of emissions from individual coal seams (parts of seams), while the emission factor from coal in post-
Methane contained in pores (fractures of waste rocks) in the form of free gas and the majority of sorbed methane will emit into mine workings underground; it is a component of ventilation emissions.

The procedure of assessment of the methane quantity emitted from production wastes $\left(E_{\text {eso }}\right)$ in hard coal mines is based on the relationship:

$$
E_{e s o}=S_{o} \cdot B \cdot W_{e p}
$$

where

$E_{\text {eso }}-$ methane quantity emitted from production wastes (million $\mathrm{m}^{3}$ )

$S_{o}$ - mass of originated mineral wastes (million t/year),

$B$ - share of coal substance (coal) in wastes ( $\%$ by weight),

$W_{e p}-$ emission factor from coal in post-exploitation processes $\left(\mathrm{m}^{3} / \mathrm{t} \mathrm{pcs}\right)$.

Table 2

Methane emissions from production waste generated in hard coal mines in Poland in the years 2001-2010

\begin{tabular}{|c|c|c|c|c|c|c|c|c|c|c|}
\hline No. & Year & $\begin{array}{c}\text { Total } \\
\text { output } \\
\text { quantity, } \\
\text { million t }\end{array}$ & $\begin{array}{c}\text { Quantity of } \\
\text { production } \\
\text { wastes in the } \\
\text { year, } \\
\text { million t }\end{array}$ & $\begin{array}{c}\text { Total out- } \\
\text { put quantity } \\
\text { in the } \\
\text { CMM Coal } \\
\text { Mines, } \\
\text { million t }\end{array}$ & $\begin{array}{c}\text { Quantity of } \\
\text { production } \\
\text { wastes in } \\
\text { the year in } \\
\text { CMM Coal } \\
\text { mines, } \\
\text { million t }\end{array}$ & $\begin{array}{c}\text { Coal } \\
\text { mass in } \\
\text { wastes, } \\
\text { million t }\end{array}$ & $\begin{array}{c}\text { Post- } \\
\text { exploitation } \\
\text { emission } \\
\text { factor - Final } \\
\text { variant, } \mathrm{m}^{3} / \mathrm{t}\end{array}$ & $\begin{array}{c}\text { Methane } \\
\text { emissions in } \\
\text { post- } \\
\text { exploitation } \\
\text { processes, } \\
\text { million } \mathrm{m}^{3}\end{array}$ & $\begin{array}{c}\text { Methane } \\
\text { emissions } \\
\text { in post- } \\
\text { exploitation } \\
\text { processes, } \\
\text { Gg }\end{array}$ & $\begin{array}{c}\text { Emission } \\
\text { factor from } \\
\text { post- } \\
\text { exploitation } \\
\text { wastes, } \mathrm{m}^{3} / \mathrm{t}\end{array}$ \\
\hline 1 & 2001 & 102.78 & 35.198 & 72.366 & 24.783 & 3.717 & 0.590 & 2.1933 & 1.4695 & 0.030 \\
\hline 2 & 2002 & 102.07 & 32.230 & 72.129 & 22.776 & 3.416 & 0.590 & 2.0156 & 1.3505 & 0.028 \\
\hline 3 & 2003 & 100.41 & 32.420 & 65.708 & 21.215 & 3.182 & 0.606 & 1.9285 & 1.2921 & 0.029 \\
\hline 4 & 2004 & 99.17 & 33.332 & 69.167 & 23.248 & 3.487 & 0.601 & 2.0958 & 1.4042 & 0.030 \\
\hline 5 & 2005 & 97.17 & 32.067 & 67.347 & 22.225 & 3.334 & 0.601 & 2.0036 & 1.3424 & 0.030 \\
\hline 6 & 2006 & 94.27 & 31.904 & 64.518 & 21.835 & 3.275 & 0.577 & 1.8898 & 1.2662 & 0.029 \\
\hline 7 & 2007 & 87.40 & 31.830 & 62.465 & 22.749 & 3.412 & 0.586 & 1.9996 & 1.3398 & 0.032 \\
\hline 8 & 2008 & 83.40 & 26.200 & 57.537 & 18.075 & 2.711 & 0.586 & 1.5888 & 1.0645 & 0.028 \\
\hline 9 & 2009 & 77.27 & 24.141 & 53.271 & 16.643 & 2.496 & 0.586 & 1.4629 & 0.9802 & 0.027 \\
\hline 10 & 2010 & 76.15 & 26.310 & 52.184 & 18.029 & 2.704 & 0.579 & 1.5659 & 1.0491 & 0.030 \\
\hline
\end{tabular}

exploitation processes $\left(W_{e p}\right)$ for individual mines is calculated from the formula

$$
W_{e p}=\operatorname{Sum}\left[e_{p k} / Q_{w}\right] .
$$

Production wastes mined out during hard coal exploitation and originating during the processes of mechanical preparation and upgrading contain coal substance. Analogously to methane emissions in postexploitation processes, the procedure of estimation of emissions from production wastes should concern the methane contained in the coal substance.
For the requirements of the present study, a content of coal substance of $15 \%$ was adopted (according to Kwarciński) [12].

The assessment of methane emissions from production (mineral) wastes was carried out with reference to all hard coal mines, based on determined post-exploitation emission factors from hard coal (Table 2). The quantity of production waste generated in hard coal mines between 2001-2010 was obtained from Statistical Yearbooks and from Environmental Protection [2], [18]. 
6. INVENTORY OF METHANE EMISSIONS FROM HARD COAL MINES IN POLAND IN THE YEARS 2001-2010

The inventory of methane emissions in Polish hard coal mines has identified that the hard coal system generates methane from four sources. On that basis, the following division has been carried out on methane emissions from coal output processes (ventilation emissions and from degasification systems) and emissions from post-mining processes (emissions from post-mining processes and emissions from postproduction wastes). During the period 2001-2010, the measurement of methane emissions from mines also concerned an abandoned mine (Niwka-Modrzejów colliery) and therefore, the quantity and share of

Estimations of methane emissions from the hard coal system in Polish mines in the years 2001-2010

\begin{tabular}{|c|c|c|c|c|c|}
\hline \multirow[t]{2}{*}{ Year } & \multirow[t]{2}{*}{ Type of emissions } & $\begin{array}{c}\text { Output of } \\
\text { CMM coal } \\
\text { mines }\end{array}$ & $\begin{array}{c}\text { Methane emis- } \\
\text { sions in standard } \\
\text { conditions }\end{array}$ & $\begin{array}{l}\text { Emission } \\
\text { factor }\end{array}$ & $\begin{array}{l}\text { Methane } \\
\text { emissions }\end{array}$ \\
\hline & & million $\mathrm{t}$ & million $\mathrm{Nm}^{3}$ & $\mathrm{~m}^{3} \mathrm{CH}_{4} / \mathrm{t}$ & $\mathrm{Gg}$ \\
\hline \multirow{5}{*}{2001} & Ventilation emissions & \multirow{5}{*}{72.366} & 515.314 & 7.010 & 345.260 \\
\hline & Emissions from degasification systems & & 85.185 & 0.990 & 57.074 \\
\hline & Emissions from post-mining processes & & 43.379 & 0.590 & 29.064 \\
\hline & Emissions from production wastes dumping sites & & 2.193 & 0.030 & 1.469 \\
\hline & Total hard coal mining industry & & 646.071 & 8.620 & 432.867 \\
\hline \multirow{5}{*}{2002} & Ventilation emissions & \multirow{5}{*}{72.129} & 538.660 & 7.284 & 360.902 \\
\hline & Emissions from degasification systems & & 82.894 & 0.996 & 55.539 \\
\hline & Emissions from post-mining processes & & 43.092 & 0.590 & 28.872 \\
\hline & Emissions from production wastes dumping sites & & 2.016 & 0.028 & 1.350 \\
\hline & Total hard coal mining industry & & 666.662 & 8.898 & 446.663 \\
\hline \multirow{5}{*}{2003} & Ventilation emissions & \multirow{5}{*}{65.708} & 548.487 & 8.457 & 367.486 \\
\hline & Emissions from degasification systems & & 96.612 & 1.353 & 64.730 \\
\hline & Emissions from post-mining processes & & 40.641 & 0.606 & 27.229 \\
\hline & Emissions from production wastes dumping sites & & 1.928 & 0.029 & 1.292 \\
\hline & Total hard coal mining industry & & 687.669 & 10.445 & 460.738 \\
\hline \multirow{5}{*}{2004} & Ventilation emissions & \multirow{5}{*}{69.167} & 556.020 & 7.640 & 372.534 \\
\hline & Emissions from degasification systems & & 102.569 & 1.281 & 68.721 \\
\hline & Emissions from post-mining processes & & 42.392 & 0.601 & 28.402 \\
\hline & Emissions from production wastes dumping sites & & 2.096 & 0.030 & 1.404 \\
\hline & Total hard coal mining industry & & 703.076 & 9.552 & 471.061 \\
\hline \multirow{5}{*}{2005} & Ventilation emissions & \multirow{5}{*}{67.347} & 576.200 & 8.075 & 386.054 \\
\hline & Emissions from degasification systems & & 107.446 & 1.500 & 71.989 \\
\hline & Emissions from post-mining processes & & 40.958 & 0.601 & 27.442 \\
\hline & Emissions from production wastes dumping sites & & 2.004 & 0.030 & 1.342 \\
\hline & Total hard coal mining industry & & 726.607 & 10.206 & 486.827 \\
\hline \multirow{5}{*}{2006} & Ventilation emissions & \multirow{5}{*}{64.518} & 537.592 & 8.332 & 360.187 \\
\hline & Emissions from degasification systems & & 126.870 & 1.966 & 85.003 \\
\hline & Emissions from post-mining processes & & 37.022 & 0.577 & 24.805 \\
\hline & Emissions from production wastes dumping sites & & 1.890 & 0.029 & 1.266 \\
\hline & Total hard coal mining industry & & 703.374 & 10.904 & 471.261 \\
\hline \multirow{5}{*}{2007} & Ventilation emissions & \multirow{5}{*}{62.465} & 590.090 & 9.427 & 395.361 \\
\hline & Emissions from degasification systems & & 99.630 & 1.637 & 66.752 \\
\hline & Emissions from post-mining processes & & 35.867 & 0.586 & 24.031 \\
\hline & Emissions from production wastes dumping sites & & 2.000 & 0.032 & 1.340 \\
\hline & Total hard coal mining industry & & 727.587 & 11.682 & 487.483 \\
\hline \multirow{5}{*}{2008} & Ventilation emissions & \multirow{5}{*}{57.537} & 586.677 & 10.288 & 393.074 \\
\hline & Emissions from degasification systems & & 113.816 & 2.137 & 76.256 \\
\hline & Emissions from post-mining processes & & 33.123 & 0.586 & 22.192 \\
\hline & Emissions from production wastes dumping sites & & 1.589 & 0.028 & 1.064 \\
\hline & Total hard coal mining industry & & 735.204 & 13.039 & 492.586 \\
\hline \multirow{5}{*}{2009} & Ventilation emissions & \multirow{5}{*}{53.271} & 576.243 & 11.150 & 386.083 \\
\hline & Emissions from degasification systems & & 96.990 & 1.815 & 64.983 \\
\hline & Emissions from post-mining processes & & 29.945 & 0.586 & 20.063 \\
\hline & Emissions from production wastes dumping sites & & 1.463 & 0.027 & 0.980 \\
\hline & Total hard coal mining industry & & 704.641 & 13.579 & 472.109 \\
\hline & Ventilation emissions & & 559.852 & 11.050 & 375.101 \\
\hline & Emissions from degasification systems & & 91.671 & 1.777 & 61.420 \\
\hline 2010 & Emissions from post-mining processes & 52.184 & 29.413 & 0.579 & 19.707 \\
\hline & Emissions from production wastes dumping sites & & 1.566 & 0.030 & 1.049 \\
\hline & Total hard coal mining industry & & 682.503 & 13.435 & 457.277 \\
\hline
\end{tabular}


methane emissions from this mine have been taken into account in the collective analyses regarding the years 2001-2002.

In Table 3, the estimation of emissions from the hard coal system for individual years has been synthetically specified.

Based on the methodology proposed to estimate methane emissions in Polish coal mines in the inventory report of Task 1.4 project Lowcarb, a final collation of the obtained volumes (in accordance with IPCC 2006 guidelines) [10] was presented. As a result, the actual emission and methane indicator values for the Polish coal mining industry were obtained (see Fig. 2).

Despite a decrease in coal production between 2001-2010, since 2008, the average emission indica- tor from the hard coal system remains steady at a level of approx. $13 \mathrm{~m}^{3} \mathrm{CH}_{4} / \mathrm{t}$. Obtained summary results of calculations of methane emissions in the Polish coal mining industry throughout the analysed period are within $433-493 \mathrm{Gg}$ (avg. $468 \mathrm{Gg}$ ).

The main assumption of the calculations and methane emission inventory (Table 3) was the approach in accordance with IPCC 2006 and the use of country specific methods (Tier 2) [10]. A detailed analysis of methane emissions from coal mines in Poland shows that there is a significant difference between the total volume of production and the volume of production in methane mines only (Table 4). That is why the analysis of variability coefficients of methane emission in hard coal mines in Poland be-

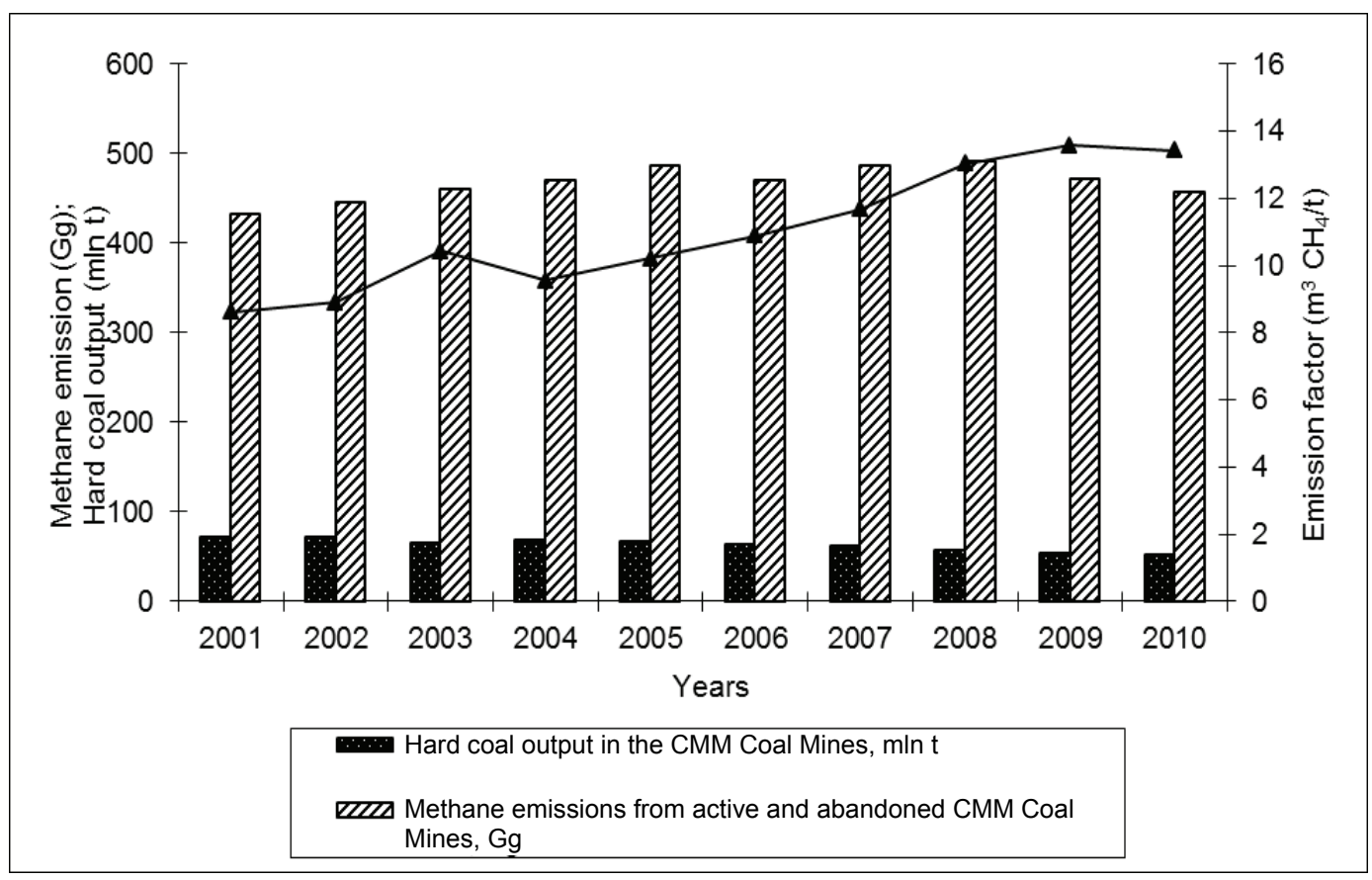

Fig. 2. Methane emission and emission factor for inventory years 2001-2010 from the exploitation of hard coal in Poland

Table 4

Uncertainty in measurement of methane emission activity in hard coal mines in Poland

\begin{tabular}{|c|c|c|c|}
\hline \multirow{2}{*}{ Year } & $\begin{array}{c}\text { Hard coal output } \\
\text { in the Coal Mines }\end{array}$ & $\begin{array}{c}\text { Hard coal output } \\
\text { in the CMM Coal Mines }\end{array}$ & $\begin{array}{c}\text { Uncertainty in measurement } \\
\text { of methane emission activity }\end{array}$ \\
\cline { 2 - 4 } & (mln tonnes) & (mln tonnes) & $\%$ \\
\hline 2001 & 102.78 & 72.37 & 27.44 \\
\hline 2002 & 102.07 & 72.13 & 27.13 \\
\hline 2003 & 100.41 & 65.71 & 34.33 \\
\hline 2004 & 99.17 & 69.17 & 26.74 \\
\hline 2005 & 97.17 & 67.35 & 27.14 \\
\hline 2006 & 94.27 & 64.52 & 29.49 \\
\hline 2007 & 87.40 & 62.47 & 27.37 \\
\hline 2008 & 83.40 & 57.54 & 30.34 \\
\hline 2009 & 77.27 & 53.27 & 31.73 \\
\hline 2010 & 76.15 & 52.18 & 32.27 \\
\hline
\end{tabular}


The estimation of methane emissions vented from coal mines according to the Polish methodology and IPCC (2006)

\begin{tabular}{|c|c|c|c|c|c|c|}
\hline Year & $\begin{array}{c}\text { Hard coal output } \\
\text { in the CMM Coal Mines, } \\
\text { million tonnes }\end{array}$ & $\begin{array}{c}\text { Emission } \\
\text { Factor, } \\
\mathrm{m}^{3} / \text { tonne }\end{array}$ & $\begin{array}{c}\text { Actual emissions of methane } \\
\text { according to the Polish } \\
\text { methodology, Gg }\end{array}$ & $\begin{array}{c}\text { Methane } \\
\text { Emissions } \\
\text { by IPCC, Gg }\end{array}$ & $\begin{array}{c}\text { The difference values } \\
\text { for emissions, Gg }\end{array}$ & $\begin{array}{c}\text { Relative error } \\
\text { of predictions } \\
\text { by IPCC, \% }\end{array}$ \\
\hline 2001 & 72.370 & 7.010 & 345.260 & 339.900 & 5.360 & 1.552 \\
\hline 2002 & 72.130 & 7.284 & 360.902 & 352.015 & 8.887 & 2.463 \\
\hline 2003 & 65.710 & 8.457 & 367.486 & 372.325 & -4.839 & -1.317 \\
\hline 2004 & 69.170 & 7.640 & 372.534 & 354.067 & 18.467 & 4.957 \\
\hline 2005 & 67.350 & 8.075 & 386.054 & 364.380 & 21.674 & 5.614 \\
\hline 2006 & 64.520 & 8.332 & 360.187 & 360.179 & 0.008 & 0.002 \\
\hline 2007 & 62.470 & 9.427 & 395.361 & 394.566 & 0.795 & 0.201 \\
\hline 2008 & 57.540 & 10.288 & 393.074 & 396.621 & -3.547 & -0.902 \\
\hline 2009 & 53.270 & 11.150 & 386.083 & 397.954 & -11.871 & -3.075 \\
\hline 2010 & 52.180 & 11.050 & 375.101 & 386.315 & -11.214 & -2.989 \\
\hline \multicolumn{2}{|l|}{ Average emission values: } & $\mathbf{8 . 8 7 1}$ & $\mathbf{3 7 4 . 2 0 4}$ & $\mathbf{3 7 1 . 8 3 2}$ & $\mathbf{2 . 3 7 2}$ & $\mathbf{0 . 6 5 1}$ \\
\hline
\end{tabular}

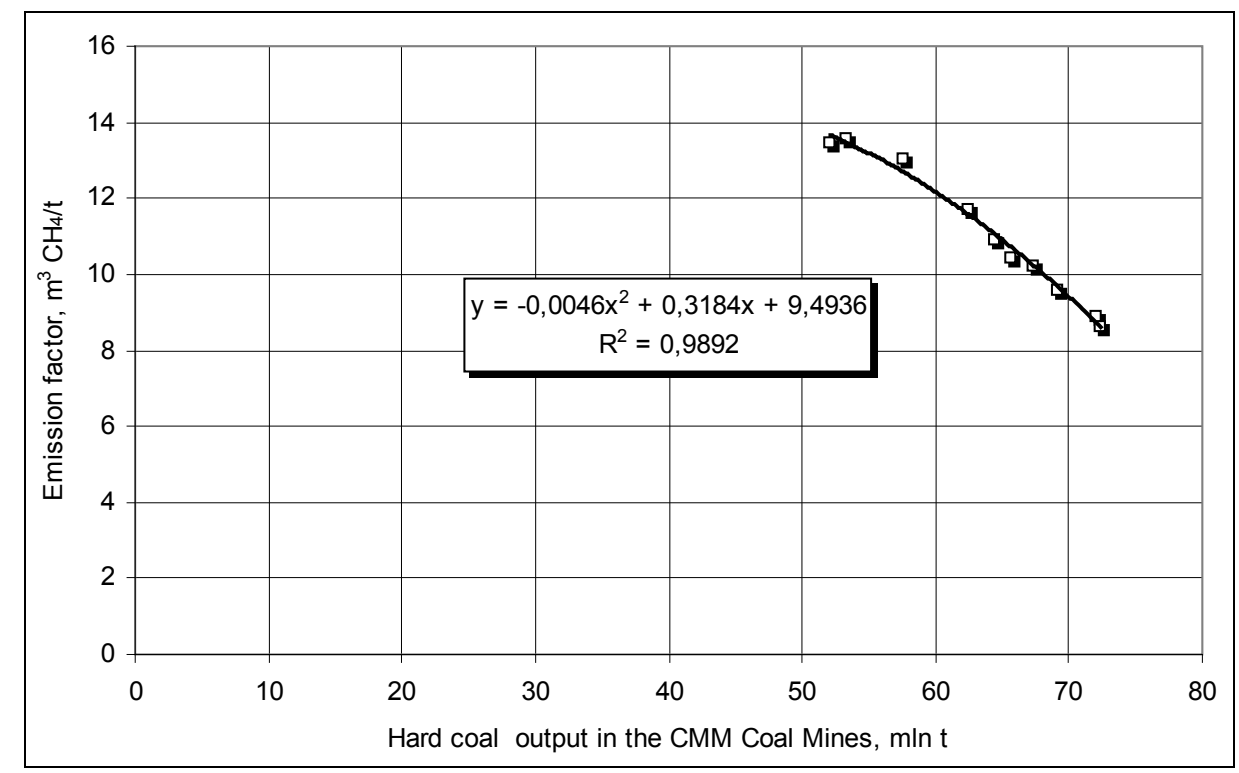

Fig. 3. Distribution of mining and post-mining methane emission factor for hard coal mines in Poland between 2001-2010

tween 2001-2010 was made. It considered the total volume of production and the volume of production in methane mines as the basis for the analysis (Fig. 2).

In Table 4, the value of total coal output and the value of coal output in methane mines were collected for each of the years 2001-2010 and assigned a variability coefficient. On that basis, it was concluded that taking into consideration output of methane coal mines the uncertainty of estimating methane emission activity decreases by approx. $29.4 \%$ [15].

Based on the above data, all the calculations of methane emissions in Poland were made, taking as the basic value - production of hard coal only in methane coal mines.
Using the proposed methodology to estimate methane emissions in Polish coal mines, the final collation of the obtained values were achieved (Table 4). The values meet IPCC 2006 [10] requirements but they are based on actual data from methane coal mines. The differences in estimating methane ventilation emissions in Polish coal mines are a result of the difference between the actual value of methane ventilation emissions in Polish coal mines and the value calculated according to IPCC 2006 (Table 5). The value of the emission factor in both cases is identical.

From the above calculations, the relative error in predictions of methane emission estimation in coal 
mines, according to the Polish method and proposed by the IPCC, is approximately 0.651 [16].

\section{CONCLUSIONS}

In general, it is necessary to assume that the IPCC [10] guidelines are appropriate to assess methane emissions. However, it is necessary to emphasise that the estimation method refers only to the methane coal mines output and is based on the measurements of methane content. The data are based on the uncertainty of estimating methane emission activity. The average value of uncertainty of methane emission activity decreased by approximately $29.4 \%$ when it was calculated with the output of methane coal mines instead of total output.

Updating the proposed methods (IPCC 2006) for estimating methane emissions from mining and postmining processes of hard coal mines (active ones and abandoned ones) in Poland, assumes that the methane emission factor (EF) is calculated based on methane coal mine output and actual values of absolute methane content (11).

In Fig. 3, a summary distribution of emission factors (for four sources) between 2001-2010 from methane coal mines in Poland is presented. It shows a trend in agreement with the distribution of a linear function of fitness $R^{2}=0.989$. The result of verifying the method of estimating methane emissions for Polish coal mines is the equation of the methane emission factor in the following form (Fig. 3)

$$
E F=-0.0046 Q^{2}+0.3184 Q+9.4936
$$

where

$E F-$ Emission Factor, $\mathrm{m}^{3} /$ ton,

$Q$ - Hard Coal Output in the CMM Coal Mines, million tons.

Estimated emission factor $(E F)$ of the methane emission indicator according to the exploitation from the CMM Coal Mines, can be used as methodology of methane emission estimation. On this basis, you are likely to estimate the emission of methane in the subsequent years of coal mine exploitation.

\section{ACKNOWLEDGEMENTS}

This document was created by the project Lowcarb (Central Mining Institute, Katowice 2010-2013) - Low carbon mine site energy initiatives; Research Programme of the Research Fund for Coal and Steel; Contract no. RFCR-CT-2010-00004.

\section{REFERENCES}

[1] Annual Report (for the years 2001-2010) on the State of Basis Natural and Technical Hazards in the Hard Coal Mining Industry. Central Mining Institute, Katowice, 20022011.

[2] Environmental Protection in the Silesian Voivodeship (20072010), Statistical Office in Katowice, Katowice, 2011.

[3] GAWLIK L. et al., Determination of greenhouse gas emission sources connected with the exploitation of the coal system (hard and brown coal) along with the determination of emission factors in sources of the emission system, calculation of emissions for the last year using the indications of the OECD/IPCC methodology and given methodologies of current information updating, National Fund of Environmental Protection, Warsaw, 1994, (nonpublished).

[4] GAWlik L., GrzyBeK I., Methodology of estimation of methane emissions connected with coal exploitation in Poland, Mineral Raw Materials Management, Vol. II, Booklet 3, 1995.

[5] GAWlik L., GRZYBeK I., Investigation results and recommendations for uncertainty reduction and clarity improvement of inventory of fugitive methane emissions from the hard coal system, Workshop: Improvement of National Inventory of Greenhouse Gases in Poland FEWE, Warsaw, 2000.

[6] Gawlik L., GrzybeK I., Detailed investigations into emission sources and capture for the inventory of greenhouse gas emissions for 1999 with respect to fugitive emissions from the coal system, Cracow, 2001.

[7] GAWLIK L., GRZYBEK I., Estimation of methane emissions in Polish Basins (Hard Coal System), Polish Academy of Sciences, Publications IGSMiE, Cracow, 2002.

[8] IPCC (1997). Revised 1996 IPCC Guidelines for National Greenhouse Gas Inventories. Reference Manual.

[9] IPCC (2000). Good Practice Guidance and Uncertainty Management in National GHG Inventories.

[10] IPCC (2006). 2006 IPCC Guidelines for National Greenhouse Gas Inventories.

[11] Kidybiński A., PATYŃSKa R., Analysis of gas-geodynamic phenomena in hard coal mines in Poland and in the world, MONOGRAPH, Scientific Works of GIG, Katowice, reviewed by Prof. Marian Kolarczyk, 2008, 1-110.

[12] KWARCIŃSKI J., Assessment of real methane emissions into the atmosphere caused by hard coal exploitation, State Geological Institute, Sosnowiec, 2005, (non-published).

[13] National inventory of greenhouse gas emissions and absorption for 2007, Report prepared for the needs of the United Nations Framework Convention on Climate Change and Kyoto Protocol, NATIONAL ADMINISTRATOR OF THE EMISSIONS TRADING SCHEME. NATIONAL EMISSIONS INVENTORY CENTRE, Institute of Environmental Protection, Warsaw, May 2009.

[14] PATYŃSKA R., Rock mass structure and its influence on gas parameters of deposits in which coal outburst and squealer hazard occur, III Traditional International Colloquium on 
Geomechanics and Geophysics, Ostavice 06-07.05.2010, Czech Republic, 207-225, Publishers: Academy of Science of the Czech Republic, Institute of Geonics, 2010.

[15] PATYŃSKA R., Uncertainty in measurement of methane emission activity in hard coal mines in Poland years 2001-2010, (in Polish) XIX International Conference Science of Technology Materials, Targanice 11-14.09.2012, Poland, 287-298, Publications Central Mining Institute, Katowice, 2012.
[16] PATYŃSKA R., Estimation of the methane emissions from methane coal mines in Poland in years 2001-2010, (in Polish), Przegląd Górniczy, 2012, No. 12.

[17] PIG. Balance of resources of minerals and underground waters in Poland. State for the year 2007. State Geological Institute, Warsaw, 2008.

[18] Statistical Yearbook of the Silesian Voivodeship (2001-2010). Statistical Office in Katowice, Katowice. 